\title{
Estimating Rock Mass Parameters in Block and Matrix Rocks in Devoll Valley
}

\author{
Megi Rusi \\ PhD Scholar, Metropolitan University of Tirana, Faculty of Civil Engineering, Rr. Brigada VIII , Vila nr 3, Tirana, Albania
}

\begin{abstract}
Devoll Hydropower Project in Albania consists of 3 power plants stretching from the village of Maliq to Banja. For the construction of Moglice hydropower, which is the upstream plant of the cascade, a $11 \mathrm{~km}$ headrace tunnel is planed from Moglice dam to Grabove underground powerhouse. Approximately 700-800 $\mathrm{m}$ of the tunnel will cross through heterogeneous rock masses consisting of different lithology blocks embedded in a fine grained sheared matrix. Estimating the rock mass parameters of this section for tunnelling purposes has been challenging and different methods of classification have been used. The paper at hand will describe the estimation of strength and deformability parameters of the rock mass through the usage of Hoek and Brown Criteria and RocLab software. A comparison will be made with the laboratory tests results to evaluate the effectiveness of the method.
\end{abstract}

Keywords: strength, deformability, GSI, UCS, $\mathrm{m}_{\mathrm{i}}$ constant.

\section{Introduction}

The classification of heterogeneous rock masses has always been challenging for geotechnical engineers. It has always been difficult to estimate the overall behavior of this rock types although the information gathered for the single components of the rock mass may be broad. In this case the rock mass characteristics have been estimated by the usage of Hoek and Brown Criteria identified in 1997, and adjusted for the heterogeneous characteristics of the Rocks [1]. Three main input parameters have to be identified in the field for calculating the rock mass behavior. These parameters are:

- Uniaxial Compressive Strength ( USC ) $\sigma_{\mathrm{ci}}$

- The $\mathrm{m}_{\mathrm{i}}$ constant for the friction character of minerals comprising the rock

- Geological Strength Index GSI

A new set of relation have been identified between GSI, $\mathrm{m}_{\mathrm{b}}, \mathrm{s}$ and a, related to the above mentioned input parameters [2]. Than newly introduced equations for calculating $\mathrm{C}$ and $\phi$ have been used. All these calculations have been facilitated by RocLab program.

\section{Methodology}

This section describes the methods used for determining the input parameters and calculating the overall rock mass behavior.

\subsection{Uniaxial Compressive Strength of intact rocks}

UCS values can be determined through laboratory test performed in intact rock samples although for heterogeneous rock masses intact samples are difficult to be collected in the surface. Several undisturbed samples taken from geological drillings have been tested but not the entire area is covered with drillings so the simple field tests for estimating UCS has been used with grades ranging from R0 to R6 for extremely week to extremely strong rocks. From the data gathered in the field it results that block within the block and matrix rock mass vary from R3 medium strong to R5 very strong.

\section{$2.2 \mathrm{~m}_{\mathrm{i}}$ constant}

The mi constant can be estimated in laboratory from the triaxial test on rock samples, and in the field by a qualitative description as described from Hoek and Brown [3].

\begin{tabular}{|c|c|c|c|c|c|c|}
\hline \multirow{2}{*}{$\begin{array}{l}\text { Rock } \\
\text { type }\end{array}$} & \multirow[t]{2}{*}{ Class } & \multirow[t]{2}{*}{ Group } & \multicolumn{4}{|c|}{ Texture } \\
\hline & & & Coarse & Medium & Fine & Very fine \\
\hline \multirow{5}{*}{ 苔 } & \multirow[b]{2}{*}{ Plutonic } & Light & \multicolumn{2}{|c|}{$\begin{array}{cc}\text { Granite } & \text { Dionite } \\
32 \pm 3 & 25 \pm 5 \\
\text { Granodiorite } \\
(29 \pm 3)\end{array}$} & & \\
\hline & & Dark & $\begin{array}{l}\text { Gabbro } \\
27 \pm 3 \\
\text { Norite } \\
20 \pm 5\end{array}$ & $\begin{array}{l}\text { Dolerite } \\
(16 \pm 5)\end{array}$ & & \\
\hline & \multicolumn{2}{|c|}{ Hypabyssal } & \multicolumn{2}{|c|}{$\begin{array}{c}\text { Porphyries } \\
(20 \pm 5)\end{array}$} & $\begin{array}{l}\text { Diabase } \\
(15 \pm 5)\end{array}$ & $\begin{array}{c}\text { Peridotite } \\
(25 \pm 5)\end{array}$ \\
\hline & \multirow[t]{2}{*}{ Volcanic } & Lava & & $\begin{array}{c}\text { Rhyolite } \\
(25 \pm 5) \\
\text { Andesite } \\
25 \pm 5\end{array}$ & $\begin{array}{c}\text { Dacite } \\
(25 \pm 3) \\
\text { Basalt } \\
(25 \pm 5)\end{array}$ & \\
\hline & & Pyroclastic & $\begin{array}{c}\text { Agglomerate } \\
(19 \pm 3)\end{array}$ & $\begin{array}{l}\text { Volcanic breccia } \\
\quad(19 \pm 5)\end{array}$ & $\begin{array}{c}\begin{array}{c}\text { Tuff } \\
(13 \pm 5)\end{array}\end{array}$ & \\
\hline
\end{tabular}

Figure 1: mi constant values for igneous rocks [1]

The values for each material depend on the grain size, and crystalline structure. High values of the constant are related to high values of friction and interlocking. Mi has been estimated for all the rock types encountered in the studied area.

\subsection{Geological Strength Index}

The GSI value is determined based on the GSI chart for peridotites and related rocks. Area 1 of the chart includes massive peridotites with high strength and widely jointed. Joints are week and filled with serpentine. Area 2 includes poor to good peridoties or serpentine with highly alerted joints. Area 3 includes sheared and alerted serpentine. Area 4 includes highly sheared serpentine with week properties and soft fragments. The studied area can be seen to belong to area 4 with GSI values ranging from 10-20, but individual fragments can have higher value as well. 


\section{International Journal of Science and Research (IJSR)}

ISSN (Online): 2319-7064

Index Copernicus Value (2013): 6.14 | Impact Factor (2014): 5.611

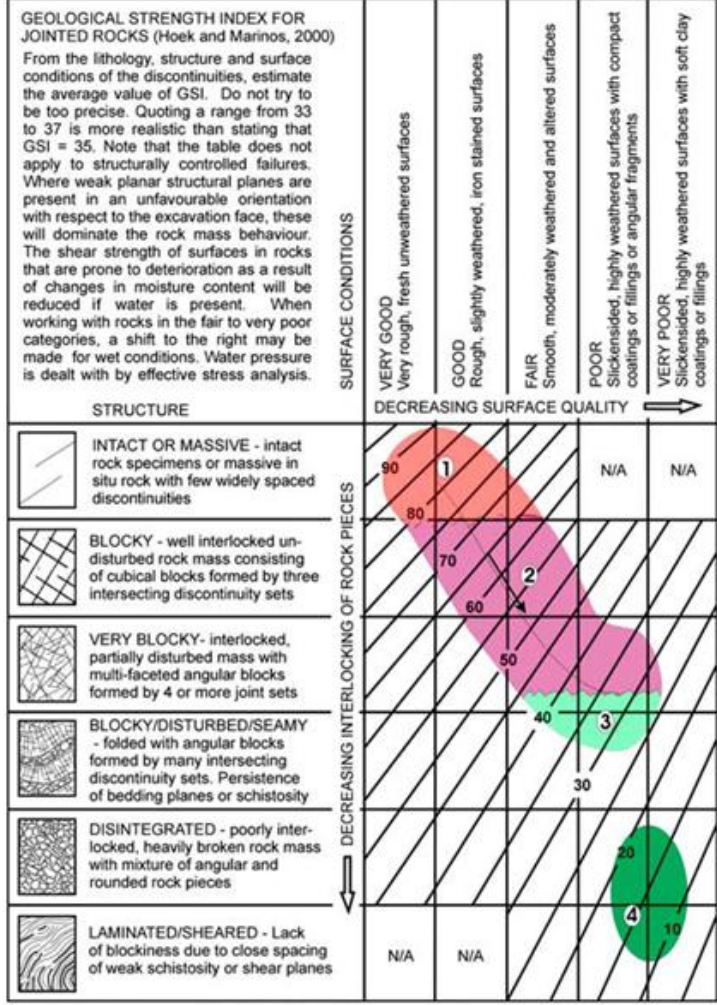

Figure 2: GSI values for peridotites and related rocks [4],[5]

\section{Determination of the Input Parameters}

Referring to the lithology and geological characteristics of the rock type encountered in the alignment of MogliceGrabove tunnel, 4 groups of rock types have been identified. The mollasic sediments, flysch rock masses, ophiolite rock mass and the mélange zone with heterogeneous characteristics which is the main objective of this paper and for engineering purposes is named the block and matrix zone. Approximately $700-800 \mathrm{~m}$ of the tunnel will cut through this rock types, and for studding purposes this stretch is divided into 5 sections and the input parameters have been determined for each rock type identified in the section. Parameters have been identified in the field with the help of Marinos and Hoek tables for UCS, mi and GSI for rocks related to peridotite [4].

\subsection{Section 1 of Block and Matrix Rocks}

Section 1 of the Block and Matrix zone is approximately $100 \mathrm{~m}$ long and is expected to cross sandstone, siltstone and sheared clay layers. The boundaries of this section are not well defined but due to the heterogeneous character of the rock mass with competent layers and shared layers it has been included in the Block and Matrix zone. The parameters determined for this section are summarized in table 1.

Table 1: Input parameters identified in the ield for section1

\begin{tabular}{|c|c|c|c|}
\hline Lithology & UCS (Mpa) & GSI & mi constant \\
\hline Siltstone/Sheared Clay & $5-25$ & $15-50$ & $7 \pm 2$ \\
\hline Sandstone & $20-40$ & $15-50$ & $6.8 \pm 4$ \\
\hline
\end{tabular}

Section 2 of the Block and Matrix zone is approximately $40 \mathrm{~m}$ long and is expected to cut mostly through clay stone and siltstone shale, with lenticular competent bodies of sandstone. The parameters determined for this section are summarized in table 2.

Table 2: Input parameters identified in the field for section 2

\begin{tabular}{|c|c|c|c|}
\hline Lithology & UCS (Mpa) & GSI & mi constant \\
\hline Siltstone- Claystone shale & $25-50$ & $15-30$ & $7 \pm 2$ \\
\hline Sandstone & $20-40$ & $15-30$ & $6.8 \pm 4$ \\
\hline
\end{tabular}

\subsection{Section 3 of Block and Matrix Rocks}

This section is $280 \mathrm{~m}$ long and is comprised by the tectonics conglobreccia which is in contact with Devoll ophiolitic massive. This rock type is considered to be the true tectonic mélange. Ophiolitic rock sequences are chaotically mixed with other rock types which represent lenticular bodies of limestone, sandstone, breccia etc. The transition between this sheared bodies and the surrounding intact rock is unpredictable and sudden.

Table 3: Input parameters identified in the field for section 3

\begin{tabular}{|c|c|c|c|}
\hline Lithology & UCS (Mpa) & GSI & mi constant \\
\hline Ophiolitic Clasts & $100-250$ & $10-25$ & $25 \pm 5$ \\
\hline Matrix & $1-25$ & $10-25$ & $8 \pm 2$ \\
\hline Limestone lenses & $50-100$ & $50-80$ & $8 \pm 2$ \\
\hline Sandstone layers & $50-100$ & $25-50$ & $8 \pm 2$ \\
\hline Volcanic Breccia & $50-100$ & $25-50$ & $8 \pm 2$ \\
\hline
\end{tabular}

\subsection{Section 4 of Block and Matrix Rocks}

Section 4 is approximately 200m long and lies mostly in intensively sheared serpentines which are part of the Ophiolitic massive of Devoll and the contact with the ophiolitic mélange. The parameters identified for this section are summarized below.

Table 4: Input parameters identified in the field for section 4

\begin{tabular}{|c|c|c|c|}
\hline Lithology & UCS (Mpa) & GSI & mi constant \\
\hline Serpentine/Lhercholite & $40-45$ & $25-40$ & $25 \pm 5$ \\
\hline Shisto Serpentine & $30-35$ & $25-40$ & $12 \pm 2$ \\
\hline sheared Serpnentine & $1-25$ & 20 -Oct & $8 \pm 2$ \\
\hline
\end{tabular}

\section{Estimating Rock Mass Parameters with RocLab}

The rock mass strength parameters have been determined by the use of RocLab software program based on Hoek and Brown failure criterion. The Hoek and Brown classification parameters identified on site for the different rock types serve as the input data for the program to determine the strength parameters which are $m_{b}, s$ and $a$. 


\section{International Journal of Science and Research (IJSR) \\ ISSN (Online): 2319-7064}

Index Copernicus Value (2013): 6.14 | Impact Factor (2014): 5.611

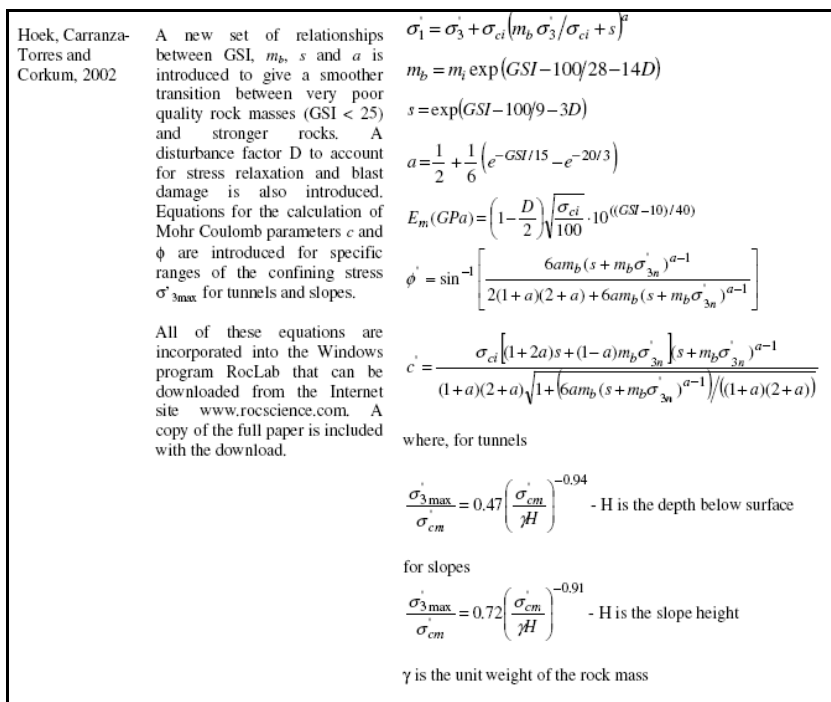

Figure 3: Equations for determining the Hoek and Brown strength parameters [2]

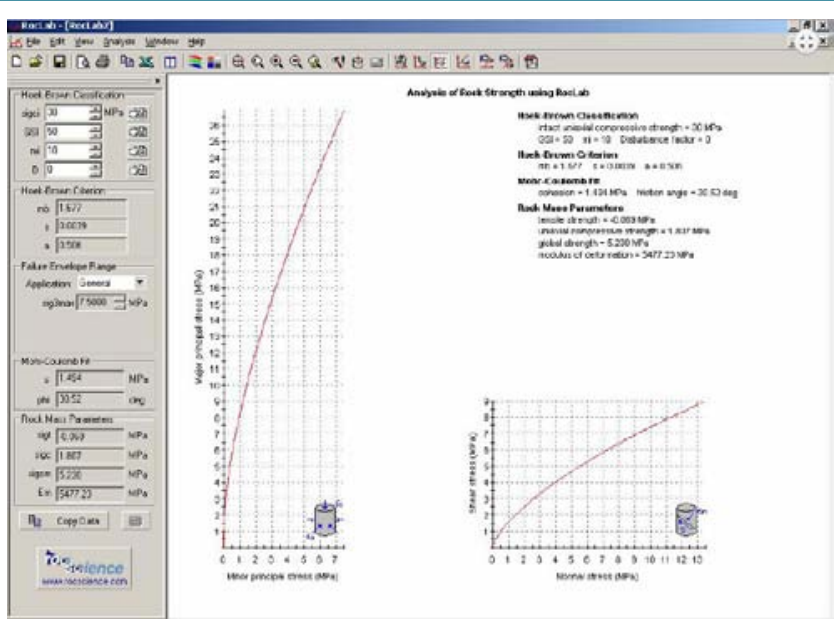

Figure 4: RocLab Working Window

In addition to the failure criterion parameters, RocLab calculates the Mohr- Coluomb fit parameters including cohesion and friction angle for the rock mass as well as tensile strength, uniaxial compressive strength, global strength and modulus of deformation.

\section{Results and interpretations}

The calculated parameters for all the encountered rock types are summarized in the table below. The laboratory test performed for determining these parameters show similar result with the parameters calculated with RocLab with only

Table 5: Output Parameters Calculated with RocLab

\begin{tabular}{|c|c|c|c|c|c|c|c|c|c|c|c|}
\hline S. No & Lithology & $\%$ & $\mathrm{mb}$ & $\mathrm{s}$ & $\mathrm{a}$ & $\mathrm{c}$ & $\mathrm{phi}$ & sigt & sigc & sig g & $\mathrm{E}$ \\
\hline \multirow{3}{*}{1} & Siltstone & 40 & 0.558 & $4.00 \mathrm{E}-04$ & 0.522 & 0.917 & 21.6 & 0.023 & 0.516 & 2.698 & 1732.1 \\
\cline { 2 - 12 } & Claystone & 60 & 0.336 & 0.0001 & 0.561 & 0.101 & 17.19 & 0.001 & 0.025 & 0.275 & 298.18 \\
\hline \multirow{3}{*}{2} & Sandstone & 40 & 0.391 & 0.0001 & 0.511 & 0.711 & 18.61 & 0.011 & 0.239 & 1.979 & 974 \\
\cline { 2 - 12 } & Claystone & 60 & 0.155 & $2.33 \mathrm{E}-05$ & 0.544 & 0.238 & 12.77 & 0.002 & 0.045 & 0.597 & 516.54 \\
\hline \multirow{4}{*}{3} & Ophiolitic Clasts & & 1.201 & 0.0001 & 0.561 & 5.094 & 27.49 & 0.01 & 0.749 & 16.786 & 1333.5 \\
\cline { 2 - 12 } & Matrix & 30 & 0.14 & $1.20 \mathrm{E}-05$ & 0.561 & 0.218 & 11.77 & 0.001 & 0.028 & 0.536 & 400.06 \\
\cline { 2 - 12 } & Limestone lenses & & 3.438 & 0.0205 & 0.502 & 4.693 & 36.5 & 0.417 & 9.938 & 18.624 & 19840 \\
\cline { 2 - 12 } & Sandstone layes & & 1.792 & $9.00 \mathrm{E}-04$ & 0.514 & 3.363 & 31.15 & 0.036 & 1.917 & 11.922 & 3958.7 \\
\cline { 2 - 12 } & Volcanic breccia & & 2.003 & 0.0009 & 0.514 & 3.488 & 32.11 & 0.032 & 1.917 & 12.614 & 3958.7 \\
\hline \multirow{4}{*}{4} & Serpentine /Lhercolit & 40 & 0.981 & $1.00 \mathrm{E}-04$ & 0.52 & 1.512 & 26.08 & 0.005 & 0.36 & 4.846 & 1683 \\
\cline { 2 - 12 } & Shisto Serpentine & 10 & 0.374 & 0.0001 & 0.52 & 0.789 & 18.79 & 0.006 & 0.222 & 2.204 & 1360.4 \\
\cline { 2 - 10 } & Serpentine sheared & 50 & 0.105 & $7.46 \mathrm{E}-06$ & 0.561 & 0.142 & 10.31 & 0.001 & 0.016 & 0.341 & 323.36 \\
\hline
\end{tabular}

few slight differences. This indicates that this method is very useful for cases where drilling is not possible either due to difficult access and topography or lack of investments in a certain stage of the project or study.

\section{References}

[1] P. Marinos and E. Hoek, Estimating the geotechnical properties of heterogeneous rock masses such as Flysch; Bull. Engg. Geol. Env. 60, 85-92, 2001.

[2] Hoek, E and Marinos, P.,2007, A Brief History of the Development of the Hoek-Brown Failure Criterion, new Brazilian Jornal of Soil and Rocks, No. 2.

[3] Hoek, E. and Brown, E.T; Practical estimates on rock mass strength, International Journal of Rock Mechanics and Mining Sciences, Vol 34, No 8, 1997, pages 11651186, 1997
[4] Marinos, P; Hoek, E; Marinos, V. 2006. Variability of the engineering properties of rock masses quantified by the geological strength index: the case of ophiolites with special emphasis on tunnelling. Bulletin of Engineering Geology and Environment, 65; 129-142

[5] E. Hoek P. Marinos M. Benissi Bull Eng Geol Env (1998). Applicability of the geological strength index (GSI) classification for very weak and sheared rock masses. The case of the Athens Schist Formation. 57 : 151-160 7 Q Springer-Verlag.

[6] Sebastian Jacobs, M.Rusi, N.Bartl, Sven Jacobs, EST000600_D01_Geological Report HPP Moglice, 2011. 


\section{Author Profile}

Megi Rusi received the B.Sc. in Earth Sciences (2008) and M.Sc. degree in Engineering Geology and Hydrogeology (2010) from the Polytechnic University of Tirana, Faculty of Geology and Mining. In 2011 was accepted as a PhD candidate in Geosciences, Nnatural resources and Environment at the same faculty. During 2009-2015 she worked for the feasibility study and construction phase of Devoll Hydropower and Energji Ashta Hydropower Albania. From 2015 she is engaged as a lecturer of Applied Geology and Geotechnics at the Faculty of Civil Engineering, Metropolitan Univerity of Tirana, dedicated the scientific research office of the university as well. 